AUTHOR CORRECTION

\title{
Correction: Liquid biopsy: an evolving paradigm for the biological characterisation of plasma cell disorders
}

Sridurga Mithraprabhu, Maoshan Chen, loanna Savvidou, Antonia Reale and Andrew Spencer (iD)

(c) The Author(s), under exclusive licence to Springer Nature Limited 2021

Leukemia (2021) 35:3037; https://doi.org/10.1038/s41375-021-01399-8

Correction to: Leukemia

https://doi.org/10.1038/s41375-021-01339-6

The article Genomic analysis of cellular hierarchy in acute myeloid leukemia using ultrasensitive LC-FACSeq, written by Caner Saygin, Eileen $\mathrm{Hu}, \mathrm{Pu}$ Zhang, Steven Sher, Arletta Lozanski, Tzyy-Jye Doong, Deedra Nicolet, Shelley Orwick, Jadwiga Labanowska, Jordan N. Skinner, Casey Cempre, Tierney Kauffman, Virginia M. Goettl, Nyla A. Heerema, Lynne Abruzzo, Cecelia Miller, Rosa Lapalombella, Gregory Behbehani, Alice S. Mims, Karilyn Larkin, Nicole Grieselhuber, Alison Walker, Bhavana Bhatnagar, Clara D. Bloomfield, John C. Byrd, Gerard Lozanski \& James S. Blachly, was originally published electronically on the publisher's internet portal on 21 May 2021 without open access. With the author(s)' decision to opt for Open Choice the copyright of the article changed on 16 August 2021 to (c) The Author(s) 2021 and the article is forthwith distributed under a Creative Commons Attribution. (i) Open Access This article is licensed under a Creative Commons Attribution 4.0 International License, which permits use, sharing, adaptation, distribution and reproduction in any medium or format, as long as you give appropriate credit to the original author(s) and the source, provide a link to the Creative Commons license, and indicate if changes were made. The images or other third party material in this article are included in the article's Creative Commons license, unless indicated otherwise in a credit line to the material. If material is not included in the article's Creative Commons license and your intended use is not permitted by statutory regulation or exceeds the permitted use, you will need to obtain permission directly from the copyright holder. To view a copy of this license, visit http://creativecommons. org/licenses/by/4.0/.

(C) The Author(s), under exclusive licence to Springer Nature Limited 2021 